\title{
WAYS TO USE AUTHENTIC READING AND COMPLETE TASK TYPES
}

Authentic materials are generally considered to be learning aids, especially reading skills. Reading exercises not only bring independence to learners but also build self-confidence. Among the authentic materials, the media has great potential in the study of language and culture. With the help of such materials, comparisons can be made, and discussions can be organized in the learning environment between the culture of the target language and students from different cultures. Although the position of newspapers among authentic materials has recently weakened due to the influence of the Internet, these materials are considered a rich resource for language learning. These materials are available to everyone, everywhere. This article provides detailed information on authentic reading rules. The purpose of writing this article is to explore the possibilities of language learning on the basis of authentic materials and to analyze the tasks on the use of these rules. The purpose of this article is to examine how to set up a preparation phase, what tools to use, and what tasks to choose. This article examines the methodological foundations for the use of authentic materials in the senior courses of a language university. It talks about the need to make radical changes to the existing system of teaching oral speech in a foreign language. The process of the English language as a whole and the learning process should be based on the communicative-functional principle. The teaching of oral speech should be purposeful, systematic, step-by-step, which will help to increase the effectiveness of this process. In the context of globalization, the main goal of teaching and learning foreign languages is to develop students' ability to use the language for communication purposes. Inductive, deductive, functional analysis and comparative methods were used in writing the article.

Key words: authentic materials, reading, tasks, English language, learning process.

\section{Гонджа ГАДЖИЕВА, orcid.org/0000-0001-9169-122X викладач, Азербайджанського університету мов} докторант кафедри методики викладання іноземних мов (Баку, Азербайджан) gonchahajiyeva86@gmail.com

\section{ШЛЯХИ ВИКОРИСТАННЯ АВТЕНТИЧНОГО ЧИТАННЯ ТА ПОВНИХ ТИПІВ ЗАДАЧ}

\begin{abstract}
Автентичні матеріали, як правило, вважаються навчальними посібниками, особливо навичками читання. Вправи на читання не лише приносять самостійність учням, а й формують впевненість у собі. Серед автентичних матеріалів засоби масової інформації мають великий потенціал у вивченні мови та культури. За допомогою таких матеріалів можна проводити порівняння та організовувати дискусії в навчальному середовищі між культурою иільової мови та студентами різних культур. Хоча позиції газет серед автентичних матеріалів останнім часом слабшають через вплив Інтернету, иі матеріали вважаються багатим ресурсом для вивчення мови. Ці матеріали доступні кожному та скрізь. Ця стаття містить детальну інформацію про автентичні правила читання. Метою написання иієї статті є дослідження можливостей вивчення мови на основі автентичних матеріалів та аналіз завдань щзодо використання ичи правил. Мета иієї статті дослідити, як налаштувати підготовчий етап, які інструменти використовувати та які завдання вибрати. У изій статті розглядаються методологічні основи використання автентичних матеріалів на старших курсах мовного університету. У ньому йдеться про необхідність кардинальних змін до існуючої системи навчання усного мовлення іноземною мовою. Прочес англійської мови в цүілому та процес навчання повинні базуватися на комунікативно-функиіональному принципі. Викладання усного мовлення повинно бути цілеспрямованим, систематичним, поетапним, щзо допоможе підвищити ефективність цьього процесу. В умовах глобалізації головною метою викладання та вивчення іноземних мов є розвиток у учнів здатності використовувати цую мову в комунікативних иілях. При написанні статті використовувались індуктивний, дедуктивний, функціональний аналіз та порівняльні методи.
\end{abstract}

Ключові слова: автентичні матеріали, читання, завдання, англійська мова, процес навчання. 
Introduction. Authentic materials are generally considered to be learning aids, especially reading skills. Reading exercises not only bring independence to learners but also build self-confidence. Based on Vidovson's views, it was traditionally intended to teach students simplified forms of language teaching. On the one hand, it provides learners with input capabilities, on the other hand, it facilitates the process of language acquisition. Now authentic presentation of the language is recommended. When approached from a variety of perspectives, reading is, for some, a mere set of words, while for others it is a means of teaching correct pronunciation and applying it in conversation. On the whole, reading is a purposeful activity, it is a part of our life in one form or another. 3 goals of the reading were identified: 1) Survival reading; 2) read to learn; 3) read to enjoy (Abbasov, 2007: 12). Reading to fight for life is a response to a kind of situation arising from human needs, as a result of which information is revealed (for example, road signs, advertisements and schedules). Reading for learning is a goal-oriented activity in the classroom, while reading for pleasure is food for the soul and not purposeful.

\section{Discussion}

There are 5 main types of reading activities:

1. idea of meaning;

2. the transfer of meaning from one thinker to another;

3. delivery of the message from the writer to the reader;

4. comprehension of meaning as a result of reading activity;

5. the contribution of the reader, the writer and the text to the process.

By examining two ways of reading the text, they can be summarized as follows:

Top-down and bottom-up

If the "top-down" global approach is based on finding keywords and using "schema" knowledge (background knowledge), "bottom-up" is a process that takes place in the context of poor reading skills and lack of background knowledge, based on literal translation (Abbasov, 2010: 80).

Bottom-up language processing involves students in the following processes:

- Divides the input into intelligible components.

- It already forms the ability to select and identify information, for example, to distinguish the elements that express semantic content from others.

- Helps to identify the syntactic patterns, semantic fragments and selective elements that make up the input.
- Clarifies the relationship between selective elements: lexical indicators, for example, through connectors.

Language processing in the form of "top-down" is based on context, situation and socio-cultural information. Such information is stored in schematic form and generates input by the following means:

- identifies the participants, the situation, the topic of the discourse, the type of communication;

- aims to draw conclusions from the relationship, the sequence of events and the information released;

- predicts the result.

Lack of schematic information (key situation) can only lead to humor. If we say, "Oh dear, I forgot my banana", it will only make you laugh. However, if we are aware of the situation, we will be aware that if an athlete says this in the locker room, a banana can replace the potassium and carbohydrates lost during training for 15 minutes (Allen, 1984: 120). To understand the role of context in comprehension, it is necessary to recall one of Nuna's ideas. "Meaning does not exist only in words in a book or in other ways, it also lives in the mind of the reader or listener.

Alderson sees the process as interactive, noting that bottom-up and top-down are intertwined. He argues that reading is an interactive process because even if one of the parties (the author) is not present, it is reminiscent of a conversation between them. "Topdown" predicts the meaning of the text, and "bottomup" serves to verify this fact. According to Scheme Theory, our perceptions and experiences of the world influence the filtering of what we read and learn. Based on this ongoing process, we receive and interpret new information. But who is a successful reader? This is a reader who can think normally linguistically and conceptually, who understands how world events develop, and who can change his/her mind at the right time (Bargiela, 2007: 24).

These two processes are balanced differently depending on the level of language proficiency and professionalism of the learners. Learners, even beginners, are more likely to process language in a "topdown" form (Batsford, 1989: 42). Due to the lack of lexical and syntactic knowledge in the target language, learners are more likely to take advantage of the context to engage in background knowledge and rely on their own knowledge of the subject. In general, the application of these two reading strategies gives more effective results than just focusing on accuracy.

The teacher plays the role of supervisor, counselor and feedback assistant. This is actually the application of the Minimal Teaching Strategy. In the preparatory phase, the activity is only about finding and designing suitable material. The problem for students with 
advanced language skills is not the lack of vocabulary (Stubborn, 2004: 220).

Authentic materials are mainly used in communicative language training, so when talking about tasks, it is worth noting that communicative language tasks are divided into 2 categories:

1. The "real world" provides this category with tasks that allow learners to become acquainted with practical language and skills that they may encounter outside the classroom environment.

2. This category of "pedagogical" refers to the process of language acquisition. Without the opportunity for learners to practice the skills they have acquired, they may need it in real-life situations. This is due to the teacher's choice of the right material. Therefore, teachers are faced with the difficult task of choosing the tasks that will illuminate their path and benefit the learners (Bershadsky, 2004: 93-100).

There are a number of criteria when choosing authentic materials. In this case, the main thing is that the materials are modern and meet the needs of students.

Literature from authentic materials, the perfect combination of form and expression is valued as a form of expression of universal interests and ideas. According to the theory of the reader's response, it is almost non-existent until the text is read. The meaning becomes relevant when the reader realizes the meaning and becomes a passive reader to an active user. Literature is, in fact, art. It is created jointly by both parties. The writer, with his/her linguistic prowess, uses the subtle and creative power of words to spark the reader's imagination. At what age to take advantage of it is controversial. For young learners and students with low language skills, a poem or any example of poetry is an ideal choice. Language introduction is provided through lullabies, short stories, rhythmic songs. As a result, shorter harmonic variants of phonemes are used, for example, "nana" and others are recommended instead of "banana".

1. Respect learners. It should not be forgotten that students also have the right to remain silent, and at the initial stage, students face difficulties with their cognitive abilities and intellectual requirements.

2. It is better to use non-verbal means of expression in the initial stage. The use of visualization, drawing, gestures and facial expressions gives effective results.

3. Approach the literature according to the task. Based on this, it can be said that kinetic and nonfrightening tasks are desirable in the choice of tasks. This includes reading in unison, single-answer questions, etc.

4. Selection should be made according to the level of knowledge of students.
5. It is more expedient to present authentic materials in unity. It will be more useful if students watch an audio or film version of the work they are reading.

6. Literary examples are studied in sequence from words and expressions in everyday spoken language to literary expressions.

7. It should not be forgotten that the difficulty depends mainly on the length of the text, the level of difficulty of the expressions, the number of cultural differences and the level of perception of the student.

\section{Assignments}

- In the preparatory stage, the audio version of the book is used or read aloud for 2-3 minutes. Students are then asked to visualize the passages they have read. Characters and the relationships between them are presented. Based on their choices, students turn the impression of the work into a painting.

- At the stage of preparation, a piece from the work is selected. Students then begin a brainstorming analysis. In general, it is impossible to know the meaning of all words in works. Therefore, it may be more useful to guess the meaning from the situation. Only when necessary can we discuss the meaning of the words in pairs, ask the teacher, or use a dictionary. In the analysis of the work, students first determine whether the work was written in British, American or another version. Sentences are analyzed according to length and level of difficulty. The idea that the work wants to convey is discussed, and the literary and everyday expressions are selected.

When choosing assignments, it is best for teachers to give preference to works written on universal topics. For example, love, age, war, death, childhood, and so on. Students who read works on such topics express their attitudes in accordance with their values. On the other hand, works that express the same or similar ideals can be selected and compared. During group work, students can select idioms, slangs from the work and give explanations. Another method is to use translation, no matter how traditional it may seem. After students translate into their mother tongue, other peers translate into the target language.

Among the authentic materials, the media has great potential in the study of language and culture. With the help of such materials, comparisons can be made, and discussions can be organized in the learning environment between the culture of the target language and students from different cultures. An interesting point is that students also learn body language while watching TV programs, news, weather forecasts and series. For learners from different cultures, gestures can sometimes be misunderstood. Shaking hands or kissing, eye contact during communication, how far to stand are conveyed through movies, series, 
TV programs. The main disadvantage of such authentic means is that they are passive and entertaining. Among such learning tools, only computers are more or less interactive. Given the limited focus and concentration, it is more appropriate and useful to follow the news in pieces as a way out.

Although the position of newspapers among authentic materials has recently weakened due to the influence of the Internet, these materials are considered a rich resource for language learning. These materials are available to everyone, everywhere. However, most of the information there is one-day. The newspaper is actually determined by its readers. Their demands and interests are taken into account. Newspaper advertisements are usually placed on the last page. It is $31 \%$ in the Guardian newspaper and $43 \%$ in the San newspaper. In many countries, there are newspapers dedicated exclusively to sports. In Ireland, The Irish Field and Racing Post are similar.

Newspaper headlines are a collection of linguistic, syntactic and stylistic means of expression.

The present continuous and infinitive forms are used in the headings in connection with future events. For example, "Women facing poverty in old age".

The participle is used instead of the passive voice. 15 killed in boat accident.

The present indefinite tense form is used to indicate the indirect execution of an action. "Sniper kills again at petrol station".

Instead of multi-syllable verbs and phraseological combinations, the development of single syllables, to tell off, instead of reprimand words, rap verb is used.

The use of emotionally strong nouns as adjectives is also a characteristic feature of newspapers. Like the word slump for example.

The widespread use of alliteration, assonance, homophony, and homographs is a key feature of newspaper headlines.

When talking about newspapers, the role of advertising should be emphasized. Because this is one of the main sources of income for newspapers. The main features of advertising are manifested in the abbreviation AIDA (Attention, Interest, Desire, Action).

Good advertising should first and foremost attract the reader's attention. Then the form of presentation of the advertisement should also arouse the interest of the potential buyer and motivate him/her to buy the advertised product and convince him/her that this is the product he/she is looking for. At the end of the process, the buyer will receive this product.

In order to prepare an assignment from such materials, it is necessary to pay attention to some issues. During the task, an advertisement with a low linguistic content, but rich in non-linguistic elements such as pictures and music, is selected. Before watching the ad, students are discussed with the above elements and their effects. Then the possibilities of using the same advertising in other genres are discussed. After watching the commercial, students discuss and compare how the individual elements are used, their effects, whether the advertisement can be effective only for the country in which it is shot, or the possibilities of secular use.

In another type of task, students are given an example of advertising. The class is divided into groups, and each group works on the task assigned to it. First of all, they determine whether the advertisement is formal or informal or literary genre. The other group determines the type of discourse used (dialogue, song, etc.). The third group adapts the watched advertisement to their own language and re-presents it in their native language. Ads can also be analyzed in terms of the ambiguity expressed there. Students can also participate in debates on which products (cigarettes, spirits) cannot be advertised or are effective.

There are a number of factors to consider when choosing authentic listening tasks. Here, the balance between the learner's level and the linguistic demand of the listening task is taken as the basis. To this end, the teacher must pay attention to a number of factors.

- Does the student know the words that are important for understanding the content of the listening task?

- Will the linguistic content of the text allow you to decode it?

- To what extent can it be done without fully clarifying the linguistic content of the text?

Introducing spontaneous spoken language in lower grades prevents students from achieving effective results. The level of learners must be taken into account here. For learners with low language skills, it is more convenient to use more short radio and audio materials. (busyteacher.org)Songs can also be used for this purpose. There is a wider choice for intermediate learners. Thus, for this purpose, a variety of listening tasks can be used, ranging from 4-5 minutes of news to films adapted to the level of learners. Given the linguistic competence of learners with higher language skills, they demonstrate their ability to understand both formal (ceremonial speech and political speeches) and informal (family conflict gossip). Students' wishes must be taken into account when choosing an authentic listening task. (businessenglishresources.com) For example, a teacher shows an art film in the classroom, but if the learners love adventure or action, the film will be of no use as authentic material. Therefore, the teacher should first conduct a small survey to find out what the learners like or dislike. 
Most authentic materials have a cultural content. Therefore, cultural compatibility is an important factor. On the other hand, cognitive requirements must also be taken into account. The intensity of the information, the speed of the speaker's speech, the accent, the suitability of the listening task to the syllabus and the learners must be taken into account when choosing. Sometimes there are expressions that the student has difficulty understanding. Let's look at the following examples. "The path to November is uphill all the way". As we know, November is the 11th month, but it means the presidential elections in November.

"Red-letter-days" means holidays, especially Christmas. It is necessary for the teacher to explain such expressions.

When a teacher uses channels such as the BBC or CNN, he or she must first provide students with initial information about the event. Providing initial information about the speakers, their identity, location, and the topic of conversation is more effective. If students are going to do a listening assignment on western culture, it is best for the teacher to ask them to do some research first, then discuss the results with the whole class, and have the students share their findings with their peers.

Before watching the original film in the target language, if the teacher informs the students about the genre, characters and general content of the film, the students will know what and why they are listening. As a result, authentic materials will be effective in achieving the desired result. Idioms are used more in movies. Therefore, it is very important that the teacher explains them. They sometimes express more than literary meaning. The teacher should ask students to mark them in their dictionaries. As a result, they can benefit more from these expressions in their speech ( cambridge.org).

Another way for a teacher to develop students' authentic reading and listening skills is to divide the class into 4 groups and ask each group to prepare a report on a topic. Topics can be chosen by both the teacher and the group members. After the information has been gathered, the group members should gather and discuss, and then present their reports in writing or orally. As a result, they benefit from a lot of authentic reading about the cultural values of the target language before the report. Other students listen to their peers.

Result. When listening is authentic, students sometimes complain that the pace of the speaker is fast. The most effective way to do this is to ask them to listen in the middle of the text. During the 1-minute listening, students record what they hear. Then the whole class shares their notes. After re-listening, the meaning is negotiated again. This type of assignment is important because students need to think about what is being said until they hear it. Then, based on what they hear, they speculate on what they will hear next. In this case, the topic of conversation, the relationship between the speakers, their emotions are mentioned more than them.

\section{BIBLIOGRAPHY}

1. Abbasov A. N. Pedagogy: summary and schemes (textbook for higher and secondary special schools). Baku: Translator, $2007,80 \mathrm{p}$.

2. Abbasov A. N. Pedagogy: a textbook for secondary special schools. Baku: Translator, 2010, 360 p.

3. Allen J P. B. General-purpose language teaching: a variable focus approach. In Brumfit, C. J. (ed.) 1984.268 p.

4. Bargiela-Chiappini, F., Nickerson C., Planken B. Business Discourse. Basingstoke : Palgrave Macmillan. 2007.318 p.

5. Batsford Breen, M. P. Process syllabuses for the language classroom. In C. J. Brumfit (ed.) General English Syllabus Design. (ELT Documents No. 118). London : Pergamon Press \& The British Council. 1984. 47-60; Bayramov A. S. Psychological studies. Baku: Azerneshr, 1989, 219 p.

6. Bershadsky M. E. Monitoring of cognitive development. School technologies. Education. 2004, no. 3, p. 23 -32.

7. Stubborn Q. E. Modern problems of mental process and upbringing. Baku : ADPU publication, 2004, $338 \mathrm{p}$.

8. "What Every Teacher of Business English Needs to Know. URL: https://busyteacher.org/10411-what-every-businessenglish-teacher-needs-to-know.html

9. Business English Resources. URL: www.businessenglishresources.com/

10. Cambrige Core. URL: https://www.cambridge.org/core/books/english-for-specific-purposes/449E5F788C04B222B0 C9CD58FEB16868

\section{REFERENCES}

1. Abbasov A. N. Pedagogy: summary and schemes (textbook for higher and secondary special schools). Baku: Translator, $2007,80 \mathrm{p}$.

2. Abbasov A. N. Pedagogy: a textbook for secondary special schools. Baku: Translator, 2010, 360 p.

3. Allen J P.B. General-purpose language teaching: a variable focus approach'. In Brumfit, C. J. (ed.) 1984. 268 p.

4. Bargiela-Chiappini, F., Nickerson C., Planken B. Business Discourse. Basingstoke: Palgrave Macmillan. 2007.318 p.

5. Batsford Breen, M. P. 'Process syllabuses for the language classroom'. In C. J. Brumfit (ed.) General English Syllabus Design. (ELT Documents No. 118). London : Pergamon Press \& The British Council. 1984. 47-60; Bayramov A. S. Psychological studies. Baku: Azerneshr, 1989, 219 p. 
6. Bershadsky M. E. Monitoring of cognitive development. School technologies. Education. 2004, no. 3, p. 23-32.

7. Stubborn Q. E. Modern problems of mental process and upbringing. Baku: ADPU publication, 2004, $338 \mathrm{p}$.

8. "What Every Teacher of Business English Needs to Know. URL: https://busyteacher.org/10411-what-every-businessenglish-teacher-needs-to-know.html

9. Business English Resources. URL: www.businessenglishresources.com/

10. Cambrige Core. URL: https://www.cambridge.org/core/books/english-for-specific-purposes/449E5F788C04B222B0 C9CD58FEB16868 